\title{
Covid 19 and unemployment in Germany: Corporate and government strategies
}

Covid 19 y desempleo en Alemania: estrategias corporativas y gubernamentales

Covid 19 e o desemprego na Alemanha: estratégias corporativas e governamentais

Mtro. Gerardo González Trujillo

gerardo.gonzalez@upq.mx

Universidad Politécnica de Querétaro - México ttps://orcid.org/0000-0003-4573-0472

Mtra. Deyanira Cruz Manzano

deyanira.cruz@upq.edu.mx

Universidad Politécnica de Querétaro - México

https://orcid.org/0000-0003-1253-9962

\begin{abstract}
This article provides the guidance and literature on the benefits of German corporate and Government decisions through a correlational analysis between Covid 19 and unemployment rate, therefore, it was necessary to test the hypothesis that there is a low correlation between the above variables and show that the unemployment rate is low due to German corporate and government policies and strategies. The methodology which was used, is descriptive and correlational, because it was required to know the influence of COVID 19 and the unemployment rate of German companies and describe the German corporate and government strategies due the pandemic. It was concluded that COVID 19 phenomena in Germany doesn't affect unemployment rate significatively. The German government and corporate policies, as well as, guidelines in companies have been efficiently.
\end{abstract}

Keywords: COVID 19, unemployment, corporate strategies, working hours reduction, government strategies.

\section{RESUMEN}

Este artículo proporciona la orientación y la literatura sobre los beneficios de las decisiones corporativas y gubernamentales alemanas a través de un análisis correlacional entre Covid 19 y la tasa de desempleo, por lo tanto, fue necesario probar la hipótesis de que existe una baja correlación entre las variables anteriores y mostrar que la tasa de desempleo es baja debido a las políticas y estrategias corporativas y gubernamentales alemanas. La metodología que se utilizó es descriptiva y correlacional, pues se requirió conocer la influencia de COVID 19 y la tasa de desempleo de las empresas alemanas y describir las estrategias corporativas y gubernamentales alemanas ante la pandemia. Se concluyó que el fenómeno de COVID 19 en Alemania no afecta la tasa de desempleo de manera significativa. El gobierno alemán y las políticas corporativas, así como las directrices en las empresas, han sido eficientes.

Palabras clave: COVID 19, desempleo, estrategias corporativas, reducción de horas laborales, estrategias gubernamentales.

\section{RESUMO}

Este artigo fornece orientação e literatura sobre os benefícios das decisões corporativas e governamentais alemãs por meio de uma análise correlacional entre Covid 19 e a taxa de desemprego, portanto, foi necessário testar a hipótese de que há uma baixa correlação entre as variáveis acima e mostrar que a taxa de desemprego é baixa devido às políticas e estratégias corporativas e governamentais alemãs. A metodologia utilizada é descritiva e correlacional, pois foi necessário conhecer a influência do COVID 19 e a taxa de desemprego das empresas alemãs e descrever as estratégias empresariais e governamentais alemãs frente à pandemia. Concluiu-se que o fenômeno COVID 19 na Alemanha não afeta significativamente a taxa de desemprego. O governo alemão e as políticas corporativas, bem como as diretrizes nas empresas, têm sido eficientes.

Palavras-chave: COVID 19, desemprego, estratégias corporativas, redução da jornada de trabalho, estratégias governamentais. 


\section{INTRODUCTION}

Strategies are important for every company and Government, especially facing contagious global diseases like Covid 19, which has changed and affected the world economy. "By the end of April, number of reported cases and deaths were more than 3 million and 200.000 consecutively around the world" (Ceylan et al, 2020, p. 817). At the beginning of 2020, Covid 19 "was widely viewed as a Chinese problem, and then an Italian problem has become an everybody problem" (Baldwin \& Weder di Mauro, 2020, p. 1). Nowadays, companies worldwide are running essential services, but it's imperative for leaders and project managers to reflect on the implications of Covid 19 in the short and long term, especially thinking about the best position of the people inside the company for the organizational development. To start an efficient corporate strategy, it's relevant to analyze the environment around the company and Covid 19 effects, so leaders can choose the best corporate decisions and avoid employee layoffs. Also, companies are innovating very fast, and are embracing new ways of learning and working with new technologic structures and in some cases reengineering procedures, even applying updates in Human Resources policies to keep the most of the staff and full-time workers.

The analysis of the impact of Covid 19 phenomenon in Germany in relation to unemployment, can present a useful learning to develop strategies in business management to maintain an unemployment low level. It is important to understand the economic situation in Germany and the Government practices to overcome and increase the Gross Domestic Product (GDP) during 2008 when The Great Recession took place after the U.S. housing bubble (financial crisis in the U.S. mortgage market) and the global economic crisis. "In the 2009 crisis, the German Government reacted in three ways. First, the banking sector was rescued; second, three fiscal stimulus packages were implemented; and third, the labor market was stabilized through a massive decrease in average working time" (Ehmke \& Lindner, 2014, p. 5). Just before the crisis, a lot of German workers had accumulated a considerable number of extra hours and the high costs associated with permanent workers layoffs make reductions in working hours cheaper than layoffs. The companies and the German Government promoted the strategy and mechanism of working hours reduction. With the early beginning of Covid 19 between December 2019 and January 2020, the German Government strategies "was the introduction of contact tracing systems, the mandated isolation of the few infected people, and a first information campaign mainly recommending good hand hygiene and reassuring the population that the isolation of the infected worked well" (Naumann et al, 2020, p. 193).

This article provides the guidance and literature on the benefits of German corporate and Government decisions through a correlational analysis between Covid 19 and unemployment rate, therefore, it is necessary to test the hypothesis that there isn't a significant correlation between the above variables and show that the unemployment rate is low due to German corporate and government policies and strategies. What can be a threat like Covid 19, can become an opportunity to design new routes and step outside of a comfort zone, avoiding applying layoffs as a traditional easy way to reduce costs. The article begins with the conceptualization of Covid 19 in Germany related to the expected actions of workers to respond at the beginning of the pandemic. The next part is about the context of unemployment in Germany and corporate actions, as well as Government actions, is explained. Next, the methodology used to obtain the data and perform the correlation is analyzed. It seeks to answer what is the correlation between illnesses and deaths related to the unemployment variable, starting from the hypothesis that it doesn't exist a significant correlation. Finally, the conclusions reached with the hypothesis test of the correlation variables are presented.

\section{FRAMEWORK}


At the end of the year 2019, in Wuhan, China, appeared "an outbreak of a novel coronavirus that killed more than eighteen hundred and infected over seventy thousand individuals within the first fifty day of the epidemic" (Adnan et al, 2020, p. 92). This outbreak, "quickly surpassed the death toll of the severe acute respiratory syndrome (SARS) pandemic on February 9, 2020" (Mavragani, 2020, p. 1). For the investigation related of the healthy issues of the pandemic, "The International Committee on Taxonomy of Viruses (ICTV) named the virus as Sars-CoV-2 and the disease as COVID 19" (Adnan et al, 2020, p. 92). As of March 25, 2020, all European countries had COVID 19, facing not just health problems, also, economic and social issues. COVID 19 in Germany surpassed 43,646 confirmed cases (Mavragani, 2020, p. 1). Germany encourages different government strategies to face the pandemic situation and reduce unemployment.

Understanding unemployment is attributed to the failure of the labor market and labor policies. Worldwide, there is a consistent practice related to the salary and income, "wages are determined through a bargaining process between workers and their employers" (Rocheteau, 2006, p. 1). Unemployment happens when active labor people or person is unable to find a job or is fired, the consequence, is that the salary or the income is stopped. During COVID 19 pandemic, a lot of unemployment situations happened around the world, affecting not just companies, also, families and their status quo.

In Germany, there are two types of unemployment benefits, firstly, unemployment benefits I (Arbeitslosengeld I), which is related to the unemployed people who have been making regular contributions to the German Social Security System, it is "funded by the contributions and intended for job-seekers who have sufficiently contributed" (UNÉDIC, 2019, p. 3). The unemployment benefit II (Arbeitlosengeld II) also is known as Hartz IV, after the head of the committee exposed recommendations in 2002 that caused a restructuring of unemployment benefits, it is a basic subsistence benefit "which is intended for job-seekers who are not entitled to the insurance scheme and for the person who live with them" (UNÉDIC, 2019, p. 3).

The German government explicitly tied the implementation of the Hartz laws to an evaluation mandate, given the scope of the reform endeavor, the evaluation was commissioned by the government as a set of work packages and modules, aiming at an evaluation of both the Hartz reforms in their entirety and each particular element on its own (Jacobi \& Kluve, 2006, p. 2). The Hertz laws according with UNÉDIC (2019) introduce the following measures:

Hartz law I (2003)

- Required the salaried employees to register as job-seekers as soon as they became aware of the date of termination of their employment agreement;

- Established job recovery assistance measures, as well as the requalification measure mechanism intended for the older job-seekers;

- Enabled the job-seekers who hadn't worked long enough to be entitled to the unemployment benefits to receive continuing training aid;

- Created temporary placement offices;

- Enabled the employment offices to entrust, by way of contract, the management of back-to-work jobs to third parties;

- Softened the regulation relating to dismissals;

- Required from the job-seekers a greater mobility, considered as appropriate

Hartz law II (2003)

- Established business start-up aid (creation of the self-employed status);

- Created service vouchers for domestic employment jobs; 
- Amended certain provisions relating to mini-jobs and midi-jobs;

- Set the conditions for creating the future Job-Centers.

Hartz law III (2004)

- Reorganized the employment public service

Hartz law IV (2005)

- Reformed the unemployment benefit payment system: reduction of the length of time during which unemployment benefits are paid to 12 months (unemployment benefit I);

- Merged the long term unemployment benefit and the social aid into a single unemployment benefit II;

- Established a social aid reserved to the job-seekers unable to work. (p 7.)

COVID 19 hit most of the German Mittlestand companies, which are small and medium sized enterprises as is represented in Figure 1.

\section{Figure 1}

German Mittlestand enterprises expect significant turnover losses in Q2 2020

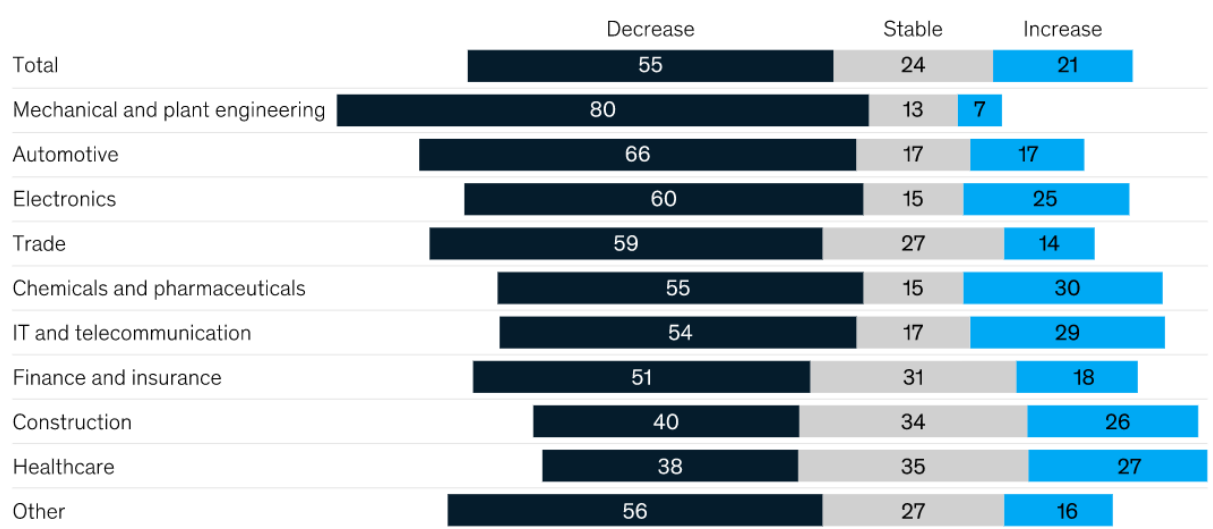

Note. Revenue outlook for Q2 2020 among German Mittlestand enterprises, \% of respondents. Retrieved from How the German Mittelstand is mastering the COVID-19 crisis, by Meffert et al, 2020. (https://www.mckinsey.com/businessfunctions/mckinsey-digital/our-insights/how-the-german-mittelstand-is-mastering-the-covid-19-crisis\#). Copyright

\section{Figure 2} 2021 by McKinsey.

Opinion on actions employers in Germany should take in response to Covid 19 in 2020

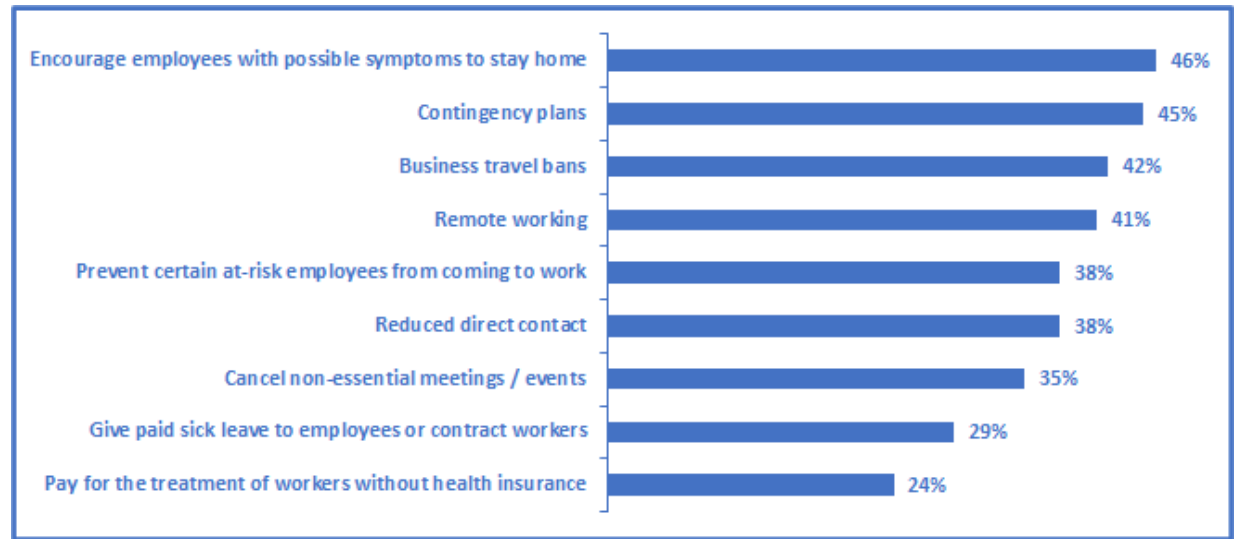


Note. Number of respondents: approx. 1,000. Age group: 18 years and older. Adapted from Opinion on the most important actions that employers in Germany should take in response to the Coronavirus outbreak, as of March 2020

by Edelman, 2020, as cited in H. Plecher, 2020, (https://www.statista.com/statistics/1105703/opinion-on-actionsgerman-employers-should-take-2020/). Copyright 2022 by Statista.

In May 2020, the expectation of the most affected industry in the second quarter (Q2) of 2020, is the Mechanical and plant engineering with $80 \%$ of turnover losses, followed by the Automotive industry. Never the less, In March 2020, the opinion on action employers in Germany that should take in response to COVID 19 is represented in Figure 2. The most important action is to Encourage employees with possible symptoms to stay home, which is the most popular action worldwide, and it is related with home office strategies.

Another corporate strategy, is the short time work, which in the past was an instrumental in keeping employment stable during the global financial crisis in 2008. Kurzarbeit is a social insurance program whereby employers reduce their employees' working hours instead of laying them off. Under Kurzarbeit, the government normally provides an income of $60 \%$ percent and increases with workers with children (IMF, 2020, paragraph 2).

\section{METHODOLOGY}

For the development of this investigation, it started with the literature analysis to identify COVID 19, unemployment, corporate strategies, working hours reduction and government strategies of German dimensions. The methodology which was use, is descriptive and correlational, because it is required to know the influence of COVID 19 and the unemployment rate of German companies and describe the German corporate and government strategies due the pandemic. For the purpose, it is taken a statistical analysis (see Table 1) about German unemployment rate, companies with short time work, COVID 19 illnesses and COVID 19 deaths.

\section{Table 1}

Statistical analysis

\begin{tabular}{cc}
\hline Analysis & Source \\
\hline $\begin{array}{c}\text { Germany: Unemployment rate from 2008 to } \\
2020\end{array}$ & $\begin{array}{c}\text { (Worldbank, 2020, as cited in H. Plecher, 2020) } \\
\text { Companies with short-time work in Germany } \\
2008-2020 \\
\text { Covid illnesses }\end{array}$ \\
Covid deaths & $\begin{array}{c}\text { Research Department, 2020) } \\
\text { (Johns Hopkins University, 2021, as cited in Statista } \\
\text { Research Department, 2021) }\end{array}$ \\
(Johns Hopkins University, 2021, as cited in Statista \\
Research Department, 2021)
\end{tabular}

Source: Own elaboration

For the main purpose, it is created two correlation statistics with the Covid illnesses and Covid deaths in relation with the Unemployment rate in Germany using 95\% confidence interval, operating the software Minitab 19 (C) (2019) to set data and generate the results of the correlation analysis. It is used the Pearson's correlation coefficient which is a statistical test for analyzing the relationship between two variables measured at an interval or ratio level. The coefficients can vary from -1.00 to 1.00 as it is represented in Table 2. It is calculated from the scores obtained in a sample in two variables. The scores collected from one variable are related to the scores obtained 
from the other, in the same cases. The test itself doesn't consider one variable as independent and another as dependent, since it doesn't assess causality (Hernández-Sampieri \& Mendoza, 2018, p. 346).

\section{Table 2}

Variation of coefficients

\begin{tabular}{cccc}
\hline Coefficient $(\mathbf{r})$ & Correlation results & Coefficient (r) & Correlation results \\
\hline-1.00 & Perfect negative & 0.10 & Very weak positive \\
-0.90 & Very strong negative & 0.25 & Weak positive \\
-0.75 & Considerable negative & 0.50 & Average positive \\
-0.50 & Average negative & 0.75 & Considerable positive \\
-0.25 & Weak negative & 0.90 & Very strong positive \\
-0.10 & Very weak negative & 1.00 & Perfect positive \\
\hline
\end{tabular}

Note: Coefficient $\mathrm{r}=0.00$ means that it doesn't exist correlation between any variable. Adapted from Metodología de la investigación - Las rutas cuantitativa, cualitativa y mixta, by R. Hernández-Sampieri and C. P. Mendoza, 2018, pp. 345-346. Copyright 2018 by McGraw Hill.

Pearson's correlation coefficient is calculated using the formula in Figure 3, where " $x$ " is equal to variable number one, " $y$ " belongs to variable number two, "zx" is the standard deviation of variable one, "zy" is the standard deviation of variable two, and " $N$ " is the data number.

\section{Figure 3}

Pearson's correlation coefficient formula

$$
r_{x y}=\frac{\sum z_{x} z_{y}}{N}
$$

Note. Retrieved from Metodología de la investigación - Las rutas cuantitativa, cualitativa y mixta, by R. HernándezSampieri and C. P. Mendoza, 2018, p. 346. Copyright 2018 by McGraw Hill.

\section{RESULTS}

In comparison with other Countries in Europe and worldwide, stepping aside de COVID 19 phenomena, Germany has encouraged strategies to avoid unemployment since before the last decade. During the Global Financial Crisis that happened in 2008, it was the only year (2008-2009) that unemployment in Germany increased less than $1 \%$, after that, unemployment in Germany has decreased from 2008 to 2020 approximately $4 \%$ as it is represented in Figure 4.

\section{Figure 4}

Germany: Unemployment rate from 2008 to 2020 


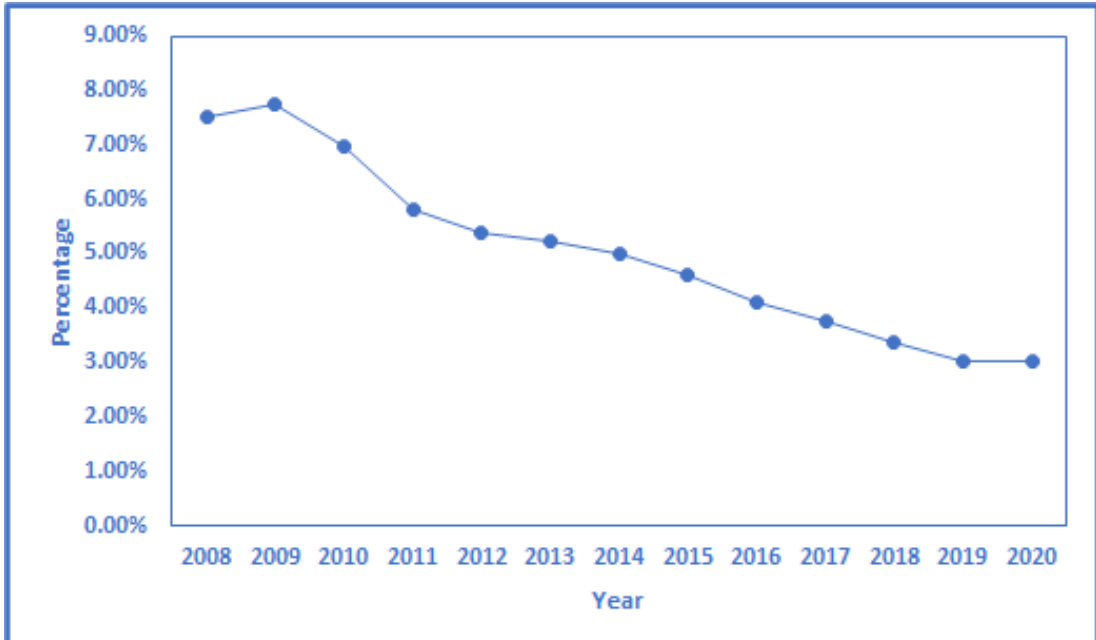

Note. In 2020, the unemployment rate in Germany was at approximately 3.03\%. Adapted from Germany:

Unemployment rate from 1999 to 2020, by Worldbank, 2020, as cited in H. Plecher, 2020 (https://www.statista.com/statistics/375209/unemployment-rate-ingermany/\#: :text=In\%202020\%2C\%20the\%20unemployment\%20rate,was\%20at\%20approximately\%203.03\%20perce nt). Copyright 2022 by Statista.

The statistic in Figure 5 shows the unemployment rate in selected world regions between 2015 and 2020. In 2020, the unemployment rate in the Arab World was estimated to have been at $11.48 \%$. In 2020, the unemployment rate in Germany was at approximately $3.03 \%$, which is a difference of $8.45 \%$ between Germany and the Arab World.

\section{Figure 5}

Unemployment rate in selected world regions between 2015 and 2020

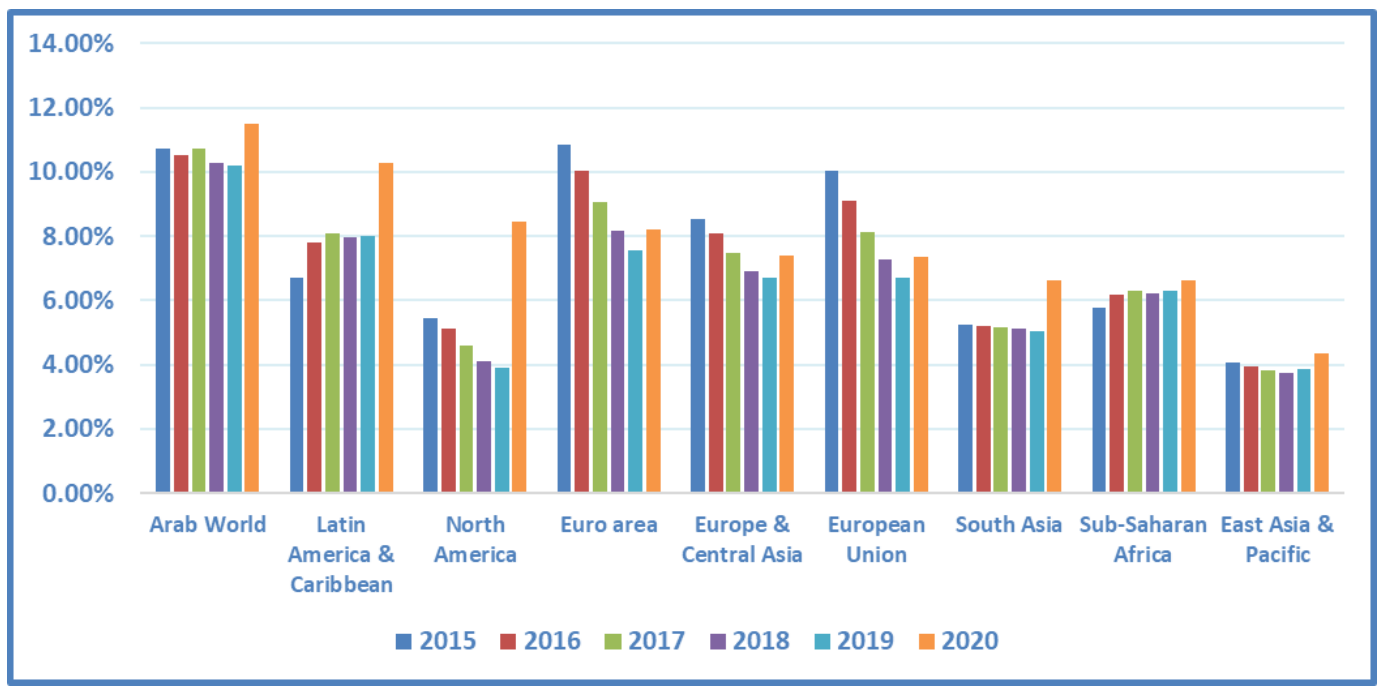

Note. Adapted from Unemployment rate in selected world regions between 2015 and 2020, by Worldbank, 2021, as cited in A. O'Neill, 2021 (https://www.statista.com/statistics/279790/unemployment-rate-in-seclected-world-regions/). Copyright 2022 by Statista.

The corporate strategy of short work, has increased significatively during 2020 due to the COVID 19 pandemic as it is represented in Figure 6. It is followed by the Global Financial Crisis of 2009.

The correlation analysis between Covid illnesses and unemployment in Germany is represented in Figure 7. It shows a Pearson with $r=0.33$ and $r^{2}=11.09 \%$ which is a weak positive correlation, likewise, it is not a representative affection to the German unemployment rate. 
The correlation analysis between Covid deaths and unemployment in Germany is represented in Figure 8. It shows a Pearson with $\mathrm{r}=0.457$ and $\mathrm{r}=20.88 \%$ which is an average positive correlation, likewise, it is not a representative affection to the German unemployment rate.

\section{Figure 6}

Companies with short-time work in Germany 2008-2020

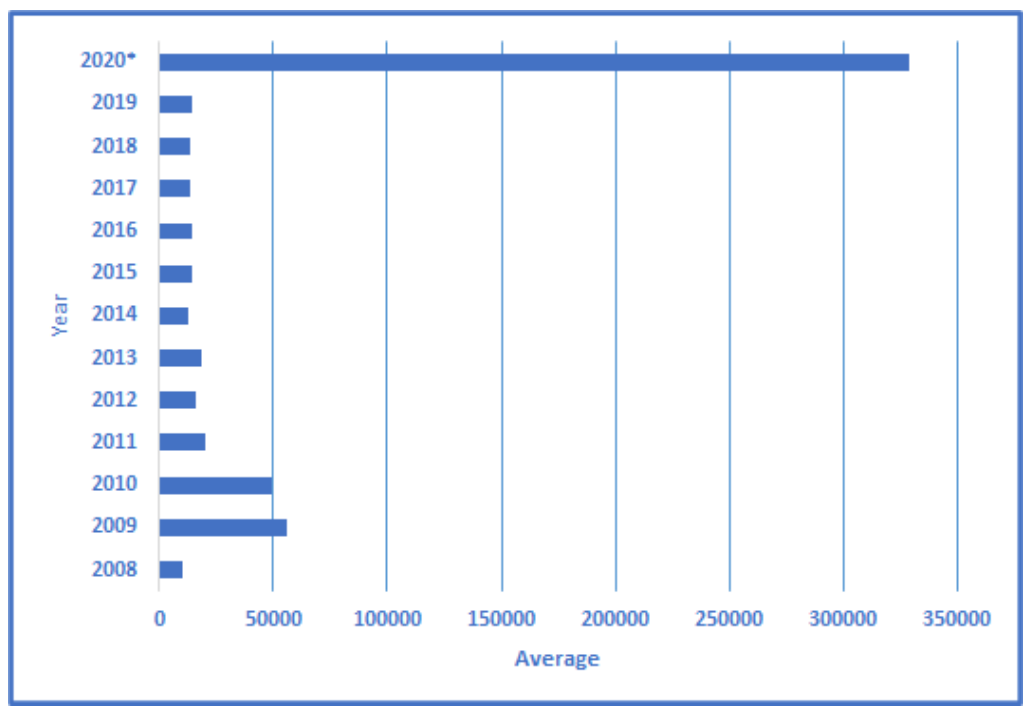

Note. ${ }^{*}$ The figure for 2020 is the average number of companies in the months from January to August. Adapted from Average number of companies with short-time work in Germany from 1992 to 2020, by Bundesagentur für Arbeitcited, 2020, as cited in Statista Research Department, 2020, (https://www.statista.com/statistics/1184437/number-companies-

\section{Figure 7} short-time-work-germany/). Copyright 2022 by Statista.

\section{Correlation between Covid illnesses and unemployment rate}

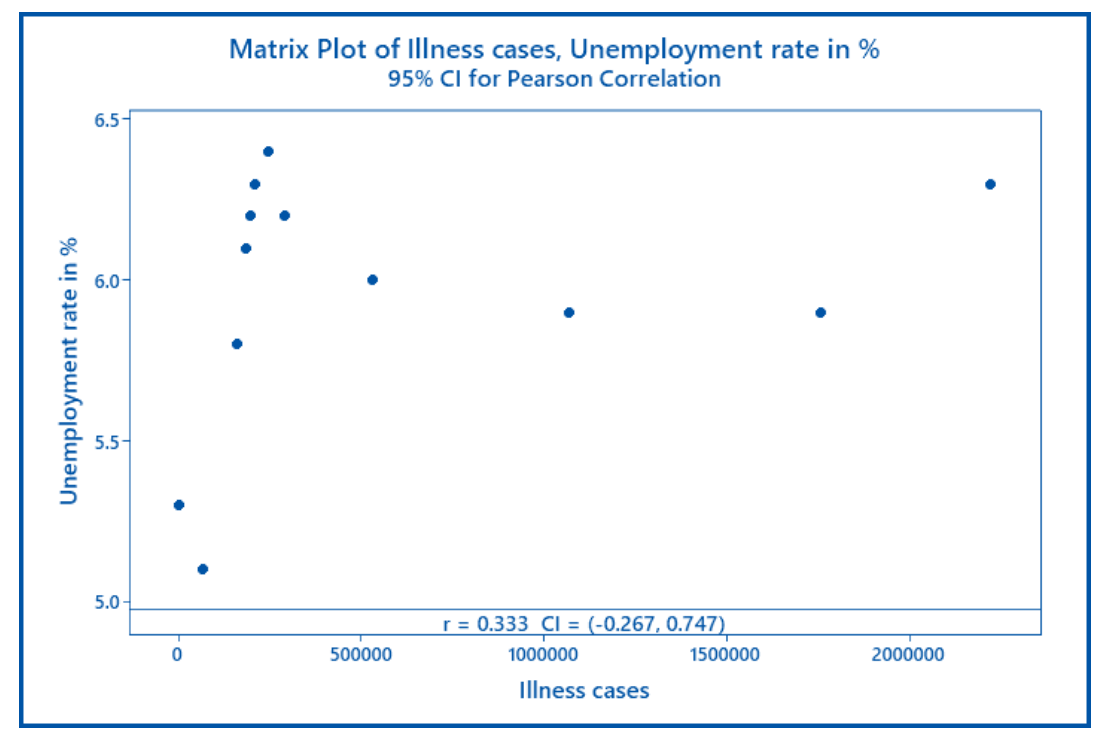

Note. Correlation type: Pearson with $\mathrm{r}=0.33$ and $\mathrm{r}^{2}=11.09 \%$ with a $95 \%$ confidence interval. Data from January 2020 to January 2021. The data for Illness cases are from Coronavirus (COVID-19) illness cases and deaths in Germany in 2021, by Johns Hopkins University, 2021, as cited in Statista Research Department, 2021,

(https://www.statista.com/statistics/1105216/coronavirus-covid-19-illness-and-death-cases-germany/). Copyright 2022 by Statista. The data for Unemployment rate are from Unemployment rate Germany, Statistics of German Federal Employment Agency, 2021, as cited in Statistisches Bundesamt, 2021,

(https://www.destatis.de/EN/Themes/Economy/Short-Term-Indicators/Labour-Market/arb210a.html). Copyright 2022 by Statistisches Bundesamt. 


\section{Figure 8}

Correlation between Covid deaths and unemployment rate

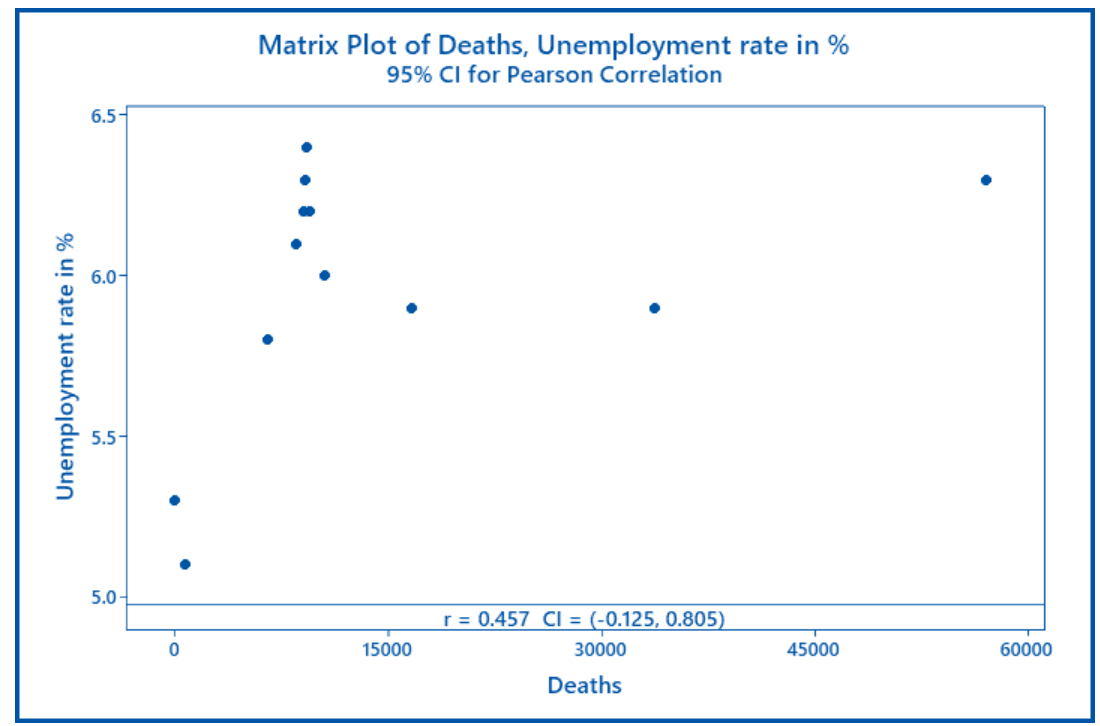

Note. Correlation type: Pearson with $\mathrm{r}=0.457$ and $\mathrm{r}^{2}=20.88 \%$ with a $95 \%$ confidence interval. Data from January 2020 to January 2021. The data for Deaths are from Coronavirus (COVID-19) illness cases and deaths in Germany in 2021, by Johns Hopkins University, 2021, as cited in Statista Research Department, 2021,

(https://www.statista.com/statistics/1105216/coronavirus-covid-19-illness-and-death-cases-germany/). Copyright 2022

by Statista. The data for Unemployment rate are from Unemployment rate Germany, Statistics of German Federal Employment Agency, 2021, as cited in Statistisches Bundesamt, 2021,

(https://www.destatis.de/EN/Themes/Economy/Short-Term-Indicators/Labour-Market/arb210a.html). Copyright 2022 by Statistisches Bundesamt.

\section{CONCLUSIONS}

After performing the analysis of the obtained results in this investigation, it concludes that COVID 19 phenomena in Germany doesn't affect unemployment rate in Germany significatively. The German government and corporate policies, as well as, guidelines in companies have been efficiently. It is necessary to analyze the strategies of the Hartz I-IV Labor Reform, and this might support companies and employees to improve collaborate activities in full time or partial time. Create a public short time work agency, is another strategy that provide singular attention to unemployed people, also the introduction of a training voucher system, so that the unemployed could match their skills to labor market demands.

Leathers of each area or department, must take the opinion of the human talent to generate strategies and new ideas to improve emotional intelligence and organizational development facing the new reality, which is the era after COVID 19. German companies have a corporate paradigm centered in values to keep and maintain the work force in different scenarios. German government has stablished laws and applied labor reforms to benefit the unemployed people, not just during the pandemic but to apply laws focused in the development of the German Nation in the closer and further future. The possibility of a shorter quarantine period must be considered, this planned action might increase the public's willingness to comply with public health recommendations and begin to impulse the economy of a Country. It is concluded that during the pandemic, Germany has demonstrated capacity and elements of success in the implementation of corporate and governmental strategies, managing to satisfy four social and political phases derived from health plans: prevention, detection, containment and action, the latter mentioned reflects the effectiveness through the development of the country's economic recovery policies. 


\section{REFERENCES}

Adnan, M., Khan, S., Kazmi, A., Bashir, N. and Siddique, R. (2020). COVID-19 infection: Emergence, transmission, and characteristics of human coronaviruses [PDF]. Journal of Advanced Research, 24, 91-98. Retrieved from https://www.sciencedirect.com/science/article/pii/S2090123220300540/pdfft?md5=9643c6b916652a92a60022 33c060cf34\&pid=1-s2.0-S2090123220300540-main.pdf

Baldwin, R. and Weder di Mauro, B. (2020). Mitigating the COVID Economic Crisis: Act Fast and Do Whatever It Takes [PDF]. CEPR Press. Retrieved from https://repository.graduateinstitute.ch/record/298223/files/COVIDEconomicCrisis.pdf\#page=174

Ceylan, R. F., Ozkan, B. and Mulazimogullari, E. (2020). Historical evidence for economic effects of COVID-19 [PDF]. The European Journal of Health Economics, 21, 817-823. Retrieved from https://link.springer.com/content/pdf/10.1007/s10198-020-01206-8.pdf

Ehmke, E. and Lindner, F. (2015). Labour Market Measures in Germany 2008-13: The Crisis and Beyond [PDF]. Switzerland: International Labour Office. Retrieved from https://www.ilo.org/wcmsp5/groups/public/--dgreports/---inst/documents/publication/wcms_449926.pdf

Hernández-Sampieri, R. and Mendoza, C. P. (2018). Metodología de la investigación-Las rutas cuantitativas, cualitativa y mixta. McGraw Hill.

IMF (2020). Kurzarbeit: Germany's Short-Time Work Benefit. Retrieved from https://www.imf.org/en/News/Articles/2020/06/11/na061120-kurzarbeit-germanys-short-time-work-benefit

Jacobi, L. and Kluve, J. (2006). Before and After the Hartz Reforms: The Performance of Active Labour Market Policy in Germany [PDF]. IZA Discussion Paper No. 2100. Retrieved from http://ftp.iza.org/dp2100.pdf

Mavragani, A. (2020). Tracking COVID-10 in Europe: Infodemiology Approach [PDF]. JMIR Public Health Suveill 2020, Volume 6, Issue 2 p. 1. Retrieved from https://publichealth.jmir.org/2020/2/e18941/PDF

Meffert, J., Mohr, N. and Richter, G. (2020). How the German Mittelstand is mastering the COVID-19 crisis [Graph]. Retrieved from https://www.mckinsey.com/business-functions/mckinsey-digital/our-insights/how-the-germanmittelstand-is-mastering-the-covid-19-crisis\#

Minitab 19 Statistical Software (2019). [Computer software]. State College, PA: Minitab, Inc. Retrieved from www.minitab.com

Naumann, E., Möhring, K., Reifensheid, M., Wenz, A., Rettig, T., Lehrer, R., Krieger, U., Juhl, S., Friedel, S., Fikel, M., Cornesse, C. \& Blom, A. (2020). COVID-19 policies in Germany and their social, political, and psychological consequences [PDF]. European Policy Analysis, Volume 6, Issue 2 p. 191-202. Retrieved from https://onlinelibrary.wiley.com/doi/epdf/10.1002/epa2.1091

O'Neill, A. (2021). Unemployment rate in selected world regions between 2015 and 2020 [Graph]. Retrieved from https://www.statista.com/statistics/279790/unemployment-rate-in-seclected-world-regions/

Plecher, H. (2020). Germany: Unemployment rate from 1999 to 2020 [Graph]. Retrieved from https://www.statista.com/statistics/375209/unemployment-rate-ingermany/\#: : text=In\%202020\%2C\%20the\%20unemployment\%20rate,was\%20at\%20approximately\%203.03 $\% 20$ percent

Plecher, H. (2020). Opinion on the most important actions that employers in Germany should take in response to the Coronavirus outbreak, as of March 2020 [Graph]. Retrieved from https://www.statista.com/statistics/1105703/opinion-on-actions-german-employers-should-take-2020/

Rocheteau, G. (2006). Understanding Unemployment [PDF]. Federal Reserve Bank of Cleveland, Economic Commentary, 10.15.2006. Retrieved from https://www.clevelandfed.org/ /media/content/newsroom\%20and\%20events/publications/economic\%20comm entary/2006/ec\%2020061015\%20economic\%20commentary\%20understanding\%20unemployment\%20pdf.pdf

Statista Research Department (2020). Average number of companies with short-time work in Germany from 1992 to 2020 [Graph]. Retrieved from https://www.statista.com/statistics/1184437/number-companies-short-timework-germany/

Statista Research Department (2020). Coronavirus (COVID-19) illness cases and deaths in Germany in 2021 [Graph]. Retrieved from https://www.statista.com/statistics/1105216/coronavirus-covid-19-illness-and-death-casesgermany/

Statistisches Bundesamt (2021). Unemployment rate Germany [Graph]. Retrieved from https://www.destatis.de/EN/Themes/Economy/Short-Term-Indicators/Labour-Market/arb210a.html

UNÉDIC (2019). Insight - The German unemployment insurance system [PDF]. Retrieved from https://www.unedic.org/sites/default/files/2020-01/Insight_Germany-unemployment-insurance-systemENG_decembre_2019.pdf 